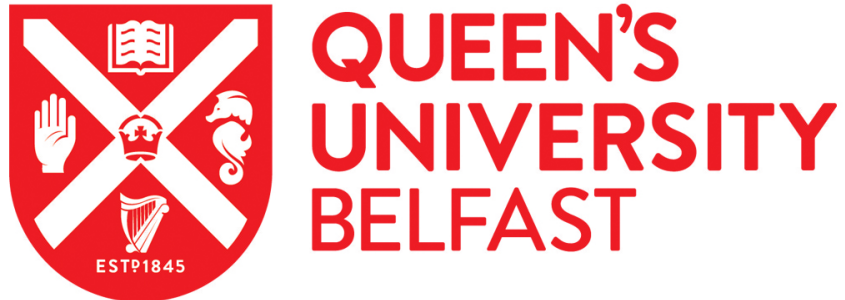

\section{Financialised Privatisation, Affordable Housing and Institutional Investment: The Case of England}

Wijburg, G., \& Waldron, R. (2020). Financialised Privatisation, Affordable Housing and Institutional Investment: The Case of England. Critical Housing Analysis. https://doi.org/10.13060/23362839.2020.7.1.508

\section{Published in:}

Critical Housing Analysis

\section{Document Version:}

Peer reviewed version

Queen's University Belfast - Research Portal:

Link to publication record in Queen's University Belfast Research Portal

Publisher rights

Copyright 2020 Critical Housing Analysis

\section{General rights}

Copyright for the publications made accessible via the Queen's University Belfast Research Portal is retained by the author(s) and / or other copyright owners and it is a condition of accessing these publications that users recognise and abide by the legal requirements associated with these rights.

Take down policy

The Research Portal is Queen's institutional repository that provides access to Queen's research output. Every effort has been made to ensure that content in the Research Portal does not infringe any person's rights, or applicable UK laws. If you discover content in the Research Portal that you believe breaches copyright or violates any law, please contact openaccess@qub.ac.uk. 


\title{
Financialised Privatisation, Affordable Housing and Institutional Investment: The Case of England
}

\author{
Gertjan Wijburg* and Richard Waldron† \\ * Department of Human Geography and Planning, Utrecht University, Utrecht, the Netherlands \\ + School of Natural and Built Environment, Queen's University Belfast, Belfast, Northern Ireland

\section{Forthcoming in Critical Housing Analysis}

\begin{abstract}
Historically, public and affordable housing has been provided by the state in close conjunction with local authorities, public housing developers, and other social housing providers. Yet, affordable rental homes are now increasingly being managed, produced, or acquired by private equity firms and other institutional investors. In this contribution, we argue that 'financialised privatisation' is a helpful concept for understanding these shifts in state-finance compromises within the post-crisis affordable housing sector. Drawing on the case of England, we first discuss the major mechanisms of financialised privatisation and examine how an increasingly polymorphous affordable housing sector has emerged with a focus on multi-tenure and mixed-income housing tenures. We then discuss the possible challenges of this transformation and conclude that it remains very much a question whether a privately funded housing system will emerge that provides genuinely affordable housing and reduces inequalities.
\end{abstract}

Keywords: financialised privatisation; financialisation; affordable housing; institutional investors.

\section{Introduction}

Across England and elsewhere, private equity funds, real estate investment trusts, and other institutional investors are increasingly entering the affordable housing market (Wainwright and Manville, 2017). 'Three examples highlight this new development. In 2017, the insurer Legal \& General announced its launch of an affordable housing arm in response to the country's 'chronic shortfall' in housing production and demographic needs for affordable living (Monoghan 2018). Legal \& General (2018) aims to construct 3,000 new affordable rental homes on an annual basis, where units can be sold to housing associations or rented out by the insurer itself. Similarly, BlackRock, the world's largest asset manager, has entered the affordable housing sector through a $£ 275$ million affordable housing project in Manchester (Cobley 2017) and partnership agreements with a series of affordable housing associations (Murden 2017). Additionally, Blackstone, the world's largest private equity fund, acquired its own 'for-profit' social housing provider, Sage Housing, which aims to construct 20,000 affordable homes between 2018 and 2023 (Williams 2018).

How can we explain such transformations in the social and affordable housing sector? The literature has typically addressed institutional investments within the third sector as a particular outcome of housing privatisation defined as 'the transfer of management, residual rights, risks and/or finance ... from the public to the private sector' (Whitehead 1993: 110). It has also associated institutional investments with broader financialisation processes within the state or the housing economy (Fields and Uffer 2016). Following Jacobs and Manzi (2019), however, we argue this current trend can be understood as a coinciding, and cumulative, outcome of both. Indeed, with the rise of 'for-profit social housing providers' in England, we see emerging practices of 'financialised privatisation', where public welfare tasks are increasingly produced, managed, and funded by institutional or corporate investors - and largely in accordance with their financial needs and expectations (Aalbers 2016). This concept captures the privatising attempts of the state to insert market logic within public or quasipublic domains (Harloe 2008), and the expansion of finance markets into non-financial domains in search of niche outlets of capital accumulation. 
Though most affordable rentals are still provided by 'traditional'ii housing associations (MHCLG, 2019), financialised privatisation may tendentially transform the third sector because the income streams of affordable housing units can now also be capitalised for broader purposes of financial profit-making. Wainwright and Manville (2017) have already demonstrated that such pressures have intensified in the aftermath of innovations in social bond markets. Thus, we hypothesise that investors are attracted by the long term nature of affordable housing as the number of 'for-profit registered providers' of affordable housing increases annually (Savills 2019). However, shifting toward more profitable forms of affordable housing and negotiating favourable local planning obligations, we suggest that England's current housing problems may not be reduced by institutional investors. Rather, as they focus on profitable investment schemes, we believe they will most likely capitalise on affordable housing issues and will not reduce inequalities accordingly.

In what follows, we first discuss the key conditions, mechanisms, and contradictions of 'financialised privatisation' with respect to the affordable housing sector, and we consider how the state has facilitated corporate landlords in capturing affordable housing revenue streams. Then we reflect on the possible challenges involved in a privately funded affordable housing sector, including the undermining of the historical public housing project and the prioritisation of private over public interests.

\section{Investment and the housing association sector}

High public expenditure has long been used to justify the liberalisation of affordable housing arrangements (Harloe 2008) in many countries. Indeed, fiscal austerity was a primary factor influencing the financialisation of affordable housing post-crash, as states looked to innovate through budget-cutting and revenue-raising exercises, which are increasingly mediated through financialised means. Such exercises include the sale of portfolios of property assets held in public 'bad banks' following the financial crisis (Byrne 2016); the roll-out of new financial investment techniques and instruments (Fields and Uffer 2016); the re-writing of development regulations or the tax code in the interests of investors (Waldron 2019; Wijburg 2019); the direct privatisation of public housing assets (Jacobs and Manzi 2019); and changes to social housing policy (Van Gent and Hochstenbach 2020).

In the UK, institutional investors have also become active funders of housing associations' financing needs because banks withdrew from retail loans after the global financial crisis (Wainwright and Manville 2017). Indeed, innovations in bond markets have enabled investors to influence the business activities and decision-making of housing associations through their bond-purchasing activities and limit housing associations from undertaking future activities that might be viewed negatively by investors. For example, UK housing associations have increasingly utilised their 2.6 million housing units as collateral in debt-raising exercises, drawing $f 23 \mathrm{bn}$ in debt from capital intermediaries between 2009 and 2015. As such, new relationships are being forged between public housing providers and private actors and these relationships are increasingly defined by new forms of financial disciplining and techno-fiscal management introducing, among others, external financial templates and managerial practices to optimise cash flow performances (Aalbers et al. 2017).

It is not hard to imagine that this trend has coincided with a broader restructuring of post-crisis urban real estate markets (Ronald et al. 2017). Rather than investing primarily in already over-inflated commercial property markets and securitised mortgages, institutional investors have now discovered affordable housing as a lower-yielding but relatively secure investment alternative (Wainwright and Manville 2017). On the supply side, investors are attracted by the devaluation of residential assets, the potential for reversionary uplift and the opportunity to utilise property assets to underpin new financial instruments (Waldron 2018). On the demand side, investors are empowered by loose 
monetary policies, while a low-growth macro-economic environment has enhanced the attractiveness of real estate as a store of wealth (Savills 2019).

Recent shifts in housing policy have also stimulated investment opportunities for institutional investors. Social housing development has been severely curtailed through recent austerity budgets, which saw capital expenditure on social housing fall from $f 11.4 \mathrm{bn}$ in 2009 to just $f 5.3 \mathrm{bn}$ in 2015 (National Housing Federation 2017). In 2017/ 2018 , 6,679 social-rental homes were built, compared to 39,562 in $2010 / 2011$, and while the latter year corresponds to the peak of the fiscal stimulus following the financial crisis, the long-term trend in social housing output has been one of decline (MHCLG 2019). As such, the social housing waiting list has lengthened significantly and many lowincome families have been forced to seek alternative accommodation options to traditional council housing.

This decline in social housing output has been accompanied by a policy shift toward the subsidisation of social housing need in the private rental sector. Indeed, in 2017, for example, the UK government spent some f8.4bn supporting 1.4 million private tenancies (Wilcox et al. 2017). While such supports clearly benefit low-income households, they also represent a considerable, and guaranteed, subsidy to private landlords and are a key attraction to investment in the affordable rental sector (Byrne 2019). Indeed, rent allowances for low-income households doubled in cash terms in the decade to 2013, while private landlords receive $40 \%$ of housing benefit payments via their tenants (Ronald and Kadi 2018).

Greater emphasis has also been placed on housing associations to fill the shortfall in social and affordable housing need, both through their own resources and increased debt financing (Smyth 2019). Changes to rent regulations from 2011 allowed for the creation of new affordable rent products, where 'affordable' rents, defined as up to $80 \%$ of the market rent value in an area, could be offered by registered social housing providers (including institutional investors). The basic premise was that higher rental thresholds could generate greater cashflows for housing associations and enable them to deliver more affordable units by sustaining higher levels of debt financing. Housing associations were also empowered to convert some of their existing stock to affordable rent, while further 'hybrid' forms of intermediate rent and shared ownership made it possible to sell affordable rental units to sitting tenants. Hence, it is this funding gap, combined with the re-regulation of rentsetting rules, that has created opportunities for investors within affordable housing.

\section{The marketisation of affordable housing}

Of course, third-sector liberalisation has affected the affordable housing sector at large. Figure 1 shows that post-crash social housing production has dropped to a historic low, from almost 40,000 units in 2010 to less than 6,500 in 2018. At the same time, it shows a dramatic expansion in alternative tenure forms. In 2018, for instance, almost 30,000 affordable rental units were delivered, while a further 17,000 units of shared ownership and 1,500 units of intermediate renting were added to England's affordable housing supply. 
Figure 1. Affordable housing production in England, 1991-2018

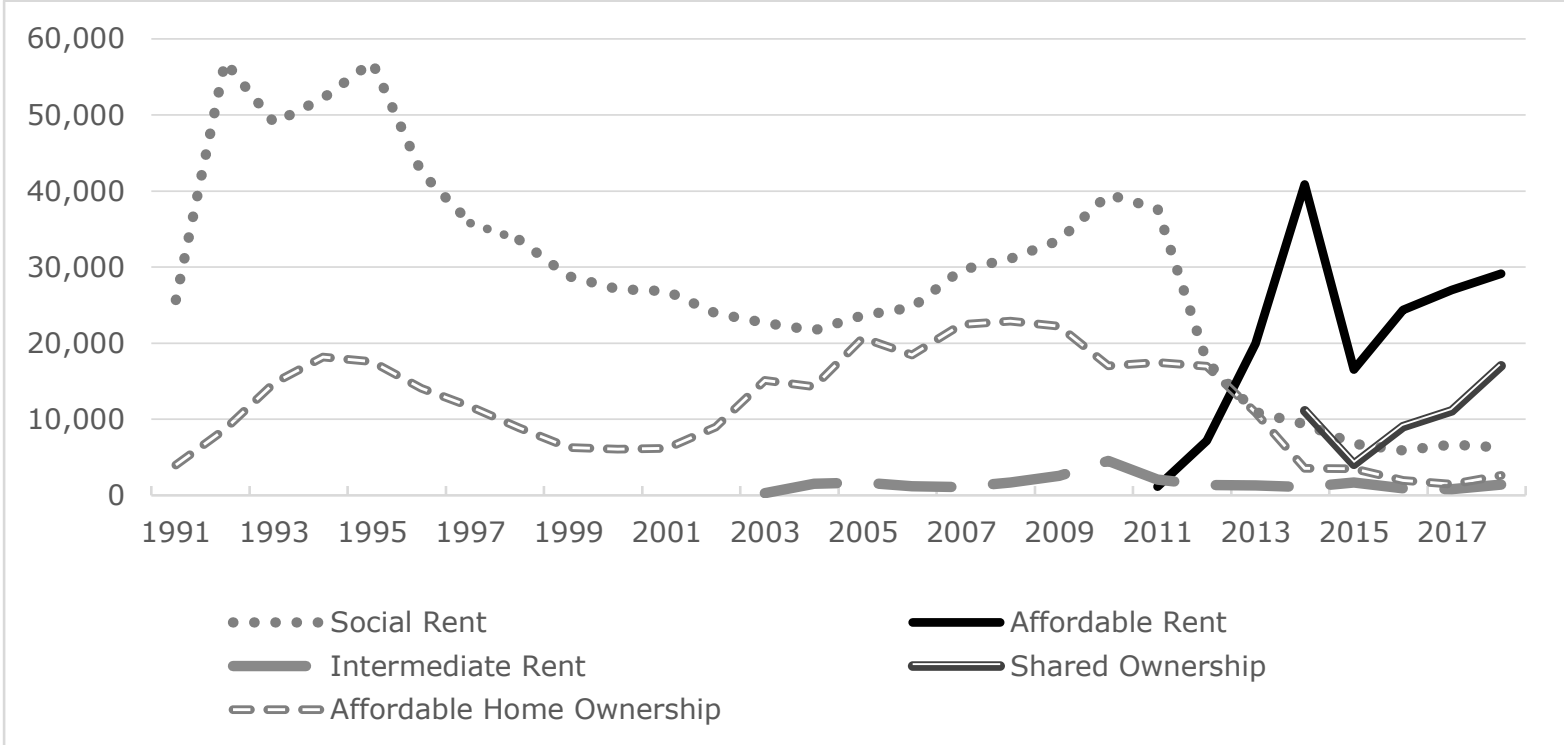

Source: (MHCLG 2019); authors' calculations.

Nevertheless, we contend that the decline of social housing and affordable homeownership vis-à-vis the growth of affordable renting, intermediate housing, or shared ownership has also created market opportunity for institutional investments. On the one hand, this hybridisation of housing tenure responds to the needs of institutional investors or commercialised housing associations looking for higher profits (Hulse et al. 2019; Nethercote 2019). On the other hand, it is also further evidence that the state is increasingly changing the collective nature of affordable housing provision. This is true not only for affordable rent and shared ownership but also for intermediate rent, which is mainly provided within London as London Living Rent (MHCLG 2019).

A further significant change emerged under the Housing and Regeneration Act 2008, which for the first time allowed for-profit social housing providers to enter the affordable market. Data from the Ministry of Housing, Communities and Local Government (2019) documents a considerable rise in 'forprofit registered providers' (FPRPs) of affordable housing with 46 registered providers now operating within the sector (Figure 2). Rather than reinvesting surpluses into existing or new housing stock, these entities are able to utilise surpluses from affordable rents or sales to distribute dividends to shareholders (Roper and Frain 2019). Therefore, not only is management, residual rights, or finance transferred to the private sector (cf. Whitehead, 1993), but so are the income streams, indicating that affordable housing units can be capitalised for financial profit-making (Evans 2019).

The first FPRP was registered in 2010 and while the number of units in this sector remains small relative to the outstanding stock of affordable housing, the pace of growth has been considerable with the number of units more than doubling between 2018 and 2019 from 2,171 to 5,342 units. The majority of acquisitions have been evenly split between shared ownership schemes and sub-market rental schemes, where yields can range from $2.75 \%$ to $5 \%$ (Savills 2019). As the 'affordable rent' subsector accounted for 58\% of all affordable housing delivery between 2016 and 2018, the expectation with in both the industry and media is that this subsector will be subject to further growth. Indeed, investors are attracted by the long-term nature of the affordable housing demand, the stable nature of returns, insulation from the volatility within other residential sub-sectors, and the potential for further sectoral growth (Evans 2019). 
Figure 2. For-profit registered providers of affordable housing

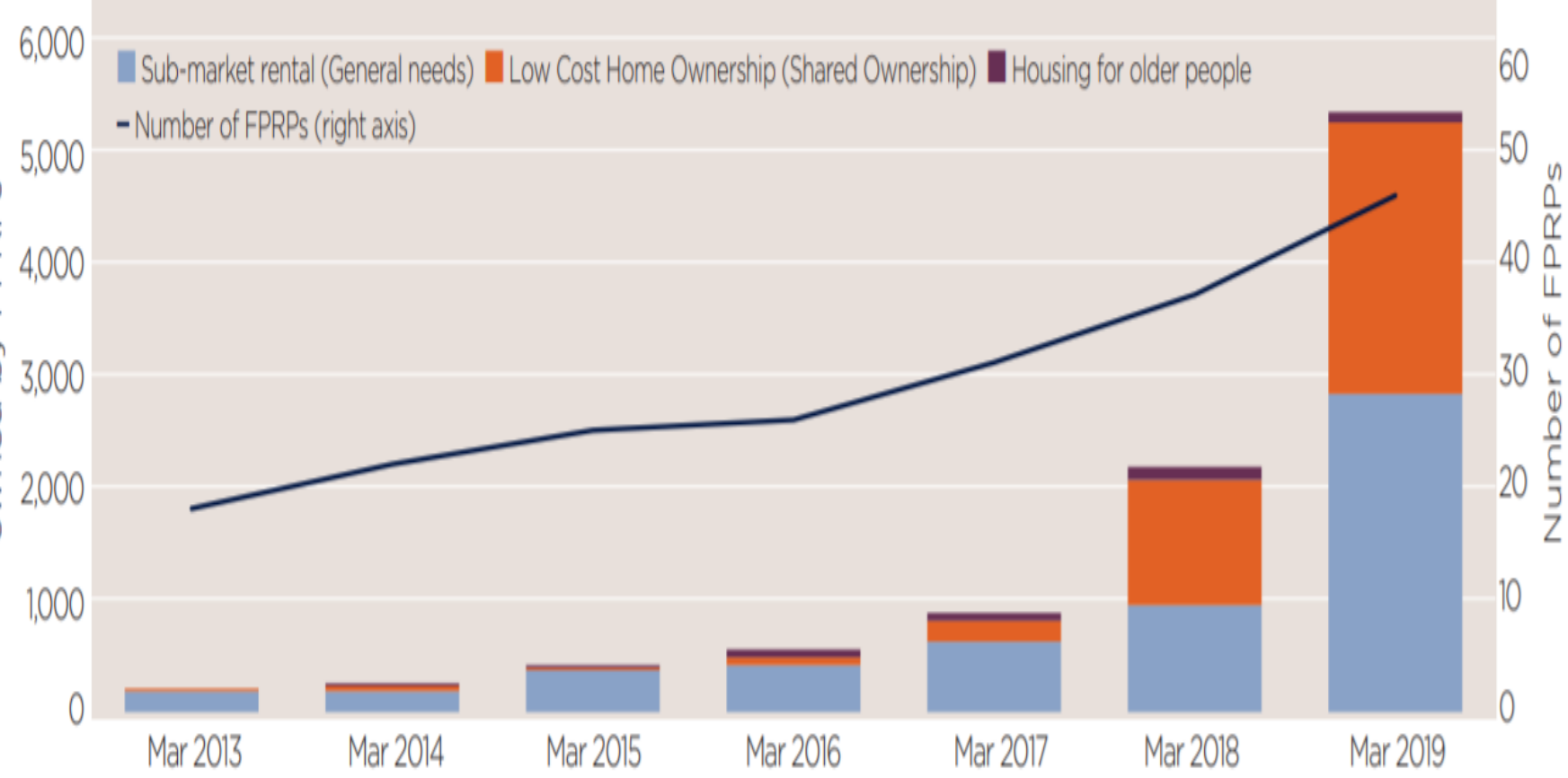

Source: (Savills 2019); data provided by the Regulator of Social Housing, 2019.

Opportunity for institutional investments also relates to how England's planning system is used. For example, much of the shift toward the privatised provision of affordable housing has been delivered through planning gain agreements. These are delivered under Section 106 of the Town and Country Planning Act 1990 and allow local authorities and developers to negotiate contributions to local infrastructure and the provision of social and affordable housing units as a condition of a planning permission for private development schemes (Whitehead 2007; Gurran and Bramley 2017). Indeed, s.106 agreements have become increasingly central to the delivery of affordable housing units, with some 287,700 units delivered between 2005 and 2018 (Stephens 2019). They have, on average, delivered $46 \%$ of all affordable units over this time period.

However, the data on s.106 agreements delivered through nil grant schemes ${ }^{\mathrm{iii}}$ (Wyatt 2018) demonstrates a marked shift toward the provision of units for affordable rent from (MHCLG 2019). Figure 3 shows that s.106 agreements delivered some 1.200 units in 2000, which increased to 28.142 units in 2018. The data also demonstrates the cyclical nature of the s.106 contribution system, in that supply increased sharply during the property bubble years of 2004 to 2008 , before contracting during the recessionary years of 2009 to 2011 (Stephens 2019). Following the 2011 reforms, the provision of affordable rental units through s.106 agreements increased markedly up to a peak of 13.000 units by 2018, while shared ownership has increased to more than 9.000 shared ownership units in the same year. 
Figure 3. Section 106 contributions (nil grant) to affordable housing production, 2000-2018.

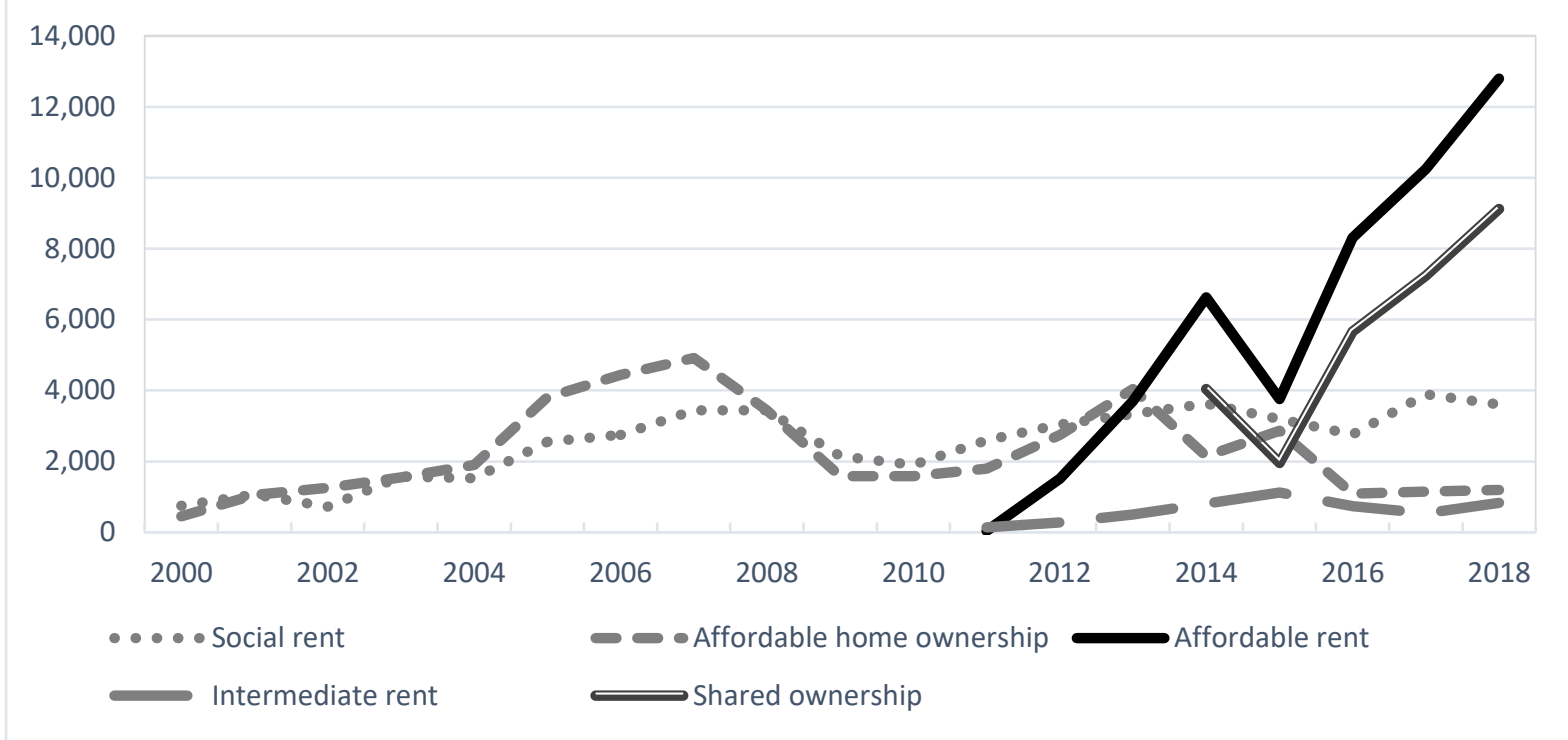

Source: (MHCLG 2019); authors' calculations.

Institutional investors and large public equity funds, who are concerned with steadily appreciating long-term income streams to fund their pension, endowment or insurance commitments, have increasingly purchased s.106 units, owing to their stable investment yields but also because traditional housing associations have been moving away from acquiring s.106 units in favour of developing land in their own right. Greater competition has also been cited as a factor, where associations have been outbidding each other for $\mathrm{s.106}$ portfolios and where some developers may increase their $\mathrm{s.106}$ prices when it is known that associations are competing for units (Wilson 2019). Such outcomes may suit better capitalised institutional investors in the sector, perhaps evident in the fact that $75 \%$ of Legal \& General's affordable housing supply comes from s.106 units (Simpson 2019). Similarly, Sage Housing (owned by Blackstone) has acquired some 7,000 s.106 units at a cost f1bn in recent years and targets an $8 \%$ return on such investments (Cross 2019). Such investors are likely concerned with the dividendproducing potential of their assets and are looking to acquire completed, ready-to-let units in highdemand locations from developers through s.106 agreements, rather than engaging in the riskier, and potentially more costly, development process.

Another aspect is that institutional investors perceive affordable housing as an opportunity to demonstrate ethical investment and social impact. For example, insurer Legal \& General (2018) has publicly adopted a 'patient capital' narrative for solving England's housing crisis with the creation of its new affordable housing arm:

'Backing a fast-growing pipeline of over 80.000 homes over the next five to ten years, we are committed to investing in...affordable housing, build-to-rent and build-to-sell...Our ambition is to be the leading long-term developer and owner of multi-tenure schemes and to accelerate the delivery of housing in the UK...'

Although such efforts could spur social housing production (Tang et al. 2017), the institutional investment model is not philanthropic and affordable rents are set at a rate of up to $80 \%$ of market rents in most parts of England and $60 \%$ in London. In dynamic markets where incidental annual growth rates of $10 \%$ are not uncommon, the $80 \%$ value of 2020 is very close to the $100 \%$ value of 2018 , thereby enabling investors to reach high (and subsidised) profit margins. Besides, affordable rental regulations allow registered housing providers to propose "a range of 'end of tenancy' options [...] including selling the property to the tenant via conversion to Shared Ownership" (Wilson and Bate 
2015: 7). Following the introduction of renewable fixed-term tenancies (Preece et al. 2019) such conversions can often be arranged or proposed after 2-5 years, but of course with the consent of the tenant. $^{\text {iv }}$ There is also potential to vertically integrate affordable housing-related services. For instance, Legal \& General advocates a 'housing eco-system' model that combines homebuilding, mortgage lending, insurance, rightsizing, and retirement lending. Inasmuch as investors help to 'solve' the affordable housing crisis, they also capitalise on it, creating tensions between public needs and private profits (cf. Wijburg 2019).

\section{Challenges of private investments: a research agenda}

Through financial innovations, planning inducements, and public-private partnerships institutional investors have become increasingly involved in the public and affordable housing sector (Beswick et al. 2016). It is too early to say whether this shift toward a polymorphous housing sector will remain the dominant pattern of the next decades. Nevertheless, we call for more critical analysis and hypothesise that institutional actors will push for more flexible, multi-tenure investment options. Unlike housing associations and less commercialised social housing providers, who have a genuine capacity to provide affordable housing (Aalbers et al. 2017), institutional investors must meet their financial expectations and are therefore more likely to exchange affordable housing commitments for more commercialised investment opportunities (JLL 2014). ${ }^{v}$

Similarly, we hypothesise that capital injections in housing associations by actors like BlackRock do not represent genuine examples of affordable housing (Cobley 2017). With its wide access to capital, BlackRock can indeed provide funding to housing associations and reduce their capital costs (Villegas 2018). However, such partnerships entail housing associations aligning their management practices with the interests of investors, leading to a greater emphasis on portfolio management to deliver higher returns through selective tenant allocation strategies and engaging in housing development for the private sector (Murden 2017; see also Fitzpatrick et al. 2019). In other words, by entering the affordable sector, institutional investors not only stand in as a quasi-public housing provider, they also put financial pressure on the sector and policymakers to further commodify affordable rental income streams (Wainwright and Manville 2017).

A key element of promoting (affordable) rental housing has been planning inducements to enhance the viability and profitability of development (McAllister 2017). In the UK development and financial sector interests have been remarkably successful in lobbying for policy transformations that support their vested interests in the housing sphere (Haughton and Allmendinger 2016). Indeed, developers and their advisors often gain access to policymakers outside the formal policymaking sphere and push through their prescriptions for system changes to enhance the profitability of development (Slater 2016). Although it is argued that the relaxation of planning regulations could help to address constraints on land supply (Cheshire 2018), such measures have also opened opportunities for development-friendly policy transformations (Bradley 2020). Such transformations could include, for example, measures to fast-track planning decisions connected with large housing developments, changes in regulatory or building regulations (e.g. allowing greater densities or taller building heights) that could allow for a greater number of housing units in a given development, or the minimisation of planning gain contributions (Waldron 2019).

The state has readily accommodated such prescriptions owing to its joint interest in promoting housing supply and the imperative for supporting economic growth, and because of ideological commitments to use planning in an instrumental fashion to facilitate investment in housing development. However, how such deals are arranged in accordance with planning regulations and how institutional investors can bypass affordable housing obligations is questions that deserve more research attention. Regarding the increased power and influence of developers and corporate 
landlords, Wainwright (2014) has stated that the UK planning system is 'overly reliant on individual negotiation between private developer and public servant, which is usually far from a level playing field'. If this is indeed the case, FPRPs and institutional investors can actively (mis)use the urban planning system to increase their rental opportunities even further.

The increase in FPRPs and the shift toward alternative tenures should also be analysed in relation to increasing socio-economic inequality and what Arundel (2017) has called 'equity inequity'. Crises and austerity, in combination with the economic insecurities surrounding Brexit, have affected lowerincome groups in the UK negatively, both in terms of housing, labour, and welfare. The historic decline of social housing production, along with the shift toward multi-tenure investment schemes, could provide a fatal blow to those lower-income groups already struggling in England. Indeed, how inequality is manifesting itself in the UK and other countries and how this relates to shifting statefinance compromises in the affordable housing sector are issues that needs to be examined more closely as well. Theoretically, institutional investors have abundant resources to help overcome England's chronic shortfall in housing production. Yet, if they mainly capitalise on their publicly subsidised housing portfolios while also investing massively in built-to-rent and land holdings (Nethercote 2019), the socio-economic picture may only worsen in the future.

\section{Conclusion}

The advent of corporate actors like BlackRock and Legal \& General in the affordable housing sphere indicates a broader reconstitution of state-capital relations, which we have referred to as financialised privatisation. Paradoxically, this phenomenon does not represent the retraction of the state from affordable housing provision but is rather a shift in its role to facilitator of corporate interests seeking to reshape the sector. Indeed, by viewing third-sector housing as a quasi-financial asset, by fostering new partnerships between housing associations and capital markets, and by creating new funding mechanisms for their penetration, the state has actively positioned affordable housing as an 'alternative asset class' for investors. Though the growth of FPRPs coincides with post-crisis transformations within England's planning system, it is not the expression of an 'unacknowledged policy regime' (Crouch 2009), because third-sector liberalisation has been integral to England's housing system for decades (Whitehead 1993).

Against that backdrop, we hypothesise that an affordable housing system is emerging in which capital markets and institutional investors, rather than the state, are acquiring, developing, and managing an increasing number of affordable rental homes (see also Aalbers et al. 2017). Our proposition is that such a housing system undermines the historical public housing project, while encouraging the commercialisation of affordable housing at the expense of the traditional social-rental model provided through local councils (Harloe 2008). Institutional investors make strategic use of these multi-tenant investment options by anticipating or reinforcing rental liberalisation, creating a mixed portfolio of 'affordable' rentals, or entertaining partnerships with housing associations and local authorities to influence the development process in accordance with their financial needs (Waldron 2019).

This kind of privately funded affordable housing system is reminiscent of the late nineteenth century, when industrial philanthropists took a leading role in affordable housing production (Harloe 2008). However, whereas the provision of affordable housing during the nineteenth century was largely a public health response to slum conditions, the current revival of the sector suits different economic imperatives. In response to conditions of fiscal austerity following the crash, state authorities and social housing providers have increasingly looked to the capital markets to provide external funding for the affordable housing sector (Fields and Uffer 2016). In return, institutional investors are willing to expand into the affordable sector as they aim to create ever more niche outlets for real estatebased capital accumulation (Aalbers 2016) and find the 'low-risk, moderate return' trade-off attractive 
in the present low-interest rate environment. While our focus in this paper has been on the English case, we note similar developments are occurring in the United States, France, and Italy where numerous experiments are emerging between for-profit actors and affordable housing providers (Gimat et al. 2020; Tapp 2019; Belotti 2017). On a European scale, the arrival of Germany-based Vonovia in Austria, France, and Sweden demonstrates another aspect of the for-profit investment model (Wijburg et al. 2018).

Whether this financialisation of the public and affordable rental sector will actually result in a housing system capable of reducing housing inequalities is controversial. Some scholars have argued for a socially fair model of housing finance, predicated on accessing land at use value and utilising longterm equity finance to enable affordable renting and homeownership (Smith 2015). However, such state-capital compromises largely depend on the state's role and how the flow of capital is regulated. Strong governance is necessary but not sufficient; social movements and civil society should also push for strong corporate governance regimes and social responsibility. Nevertheless, the emergence of institutional and corporate ownership patterns holds itself up as a mirror to the twenty-first century. More domains of society will become effectively controlled by corporate and institutional agents. Balancing the role of capital and the state will become a major governance challenge for a sustainable future.

Finally, the global outbreak of covid-19 may also change the course of affordable housing pathways. On the one hand, the crisis may lead to falling land and property values, which will certainly affect private housing supply levels in the immediate future. Falling property values and private sector rents may ease immediate affordability burdens, but this needs to be set against forecasted contractions in GDP, income, tax revenue, and a predicted sharp rise in unemployment, the impacts of which will be felt keenly along familiar class and income lines.

Still, local councils may utilise falling rents to enter into more advantageous long-term leasing arrangements to provide affordable housing, or the state may seek to expand social housing construction as an economic pump to prime activity. However, should the economic impacts of the pandemic lead to austerity measures like those witnessed following the financial crisis of 2008, then states may be encouraged to further liberalise the third sector, emphasising hybrid and more commercialised tenures over social-rental housing.

\section{References}

Aalbers, M. B. 2016. The financialization of housing: A political economy approach. New York: Routledge.

Aalbers, M. B., J. Van Loon, R. Fernandez 2017. 'The financialization of a social housing provider.' International Journal of Urban and Regional Research 41 (4): 572-587. DOI: 10.1111/14682427.12520.

Arundel, R. 2017. 'Equity Inequity: Housing Wealth Inequality, Inter and Intra-generational Divergences, and the Rise of Private Landlordism.' Housing, Theory and Society 34 (2): 176200. DOI: 10.1080/14036096.2017.1284154.

Belotti, E. 2017. 'The importation of social mix policy in Italy: A case study from Lombardy.' Cities 71 : 41-48. DOI: 10.1016/j.cities.2017.06.013.

Beswick, J., G. Alexandri, M. Byrne, S. Vives-Míro, D. Fields, S. Hodkinson, M. Janoschka 2016. 'Speculating on London's housing future: The rise of global corporate landlords in 'post-crisis' urban landscapes.' City, 20 (2): 321-341. DOI: 10.1080/13604813.2016.1145946.

Bradley, Q. 2020. 'The financialisation of housing land supply in England.' Urban Studies (in press). Firt published online March 10, 2020. DOI: 10.1177/0042098020907278.

Byrne, M. 2016. “Asset Price Urbanism' and Financialization after the Crisis: Ireland's National Asset 
Management Agency.' International Journal of Urban and Regional Research 40 (1): 31-45. DOI: 10.1111/1468-2427.12331.

Byrne, M. 2019. 'Generation rent and the financialization of housing: a comparative exploration of the growth of the private rental sector in Ireland, the UK and Spain.' Housing Studies 35 (4): $743-$ 765. DOI: 10.1080/02673037.2019.1632813.

Cheshire, P. 2018. 'Broken Market or Broken Policy? The Unintended Consequences of Restrictive Planning.' National Institute Economic Review 245 (1): 9-19 DOI: 10.1177/002795011824500111.

Cobley, M. 2017. 'BlackRock makes first private social housing loan.' The Financial News 24/01/2017. Retrieved May 12, 2020, from https://www.fnlondon.com/articles/blackrock-and-pensioncorp-ink-manchester-housing-loan-20170124.

Cross, L. 2019. 'Sage closes in on $\mathrm{f} 1 \mathrm{bn}$ affordable portfolio.' Social Housing 06/02/2019. Retrieved May 12, 2020, from https://www.socialhousing.co.uk/news/news/sage-closes-in-on-1bnaffordable-portfolio-60104.

Crouch, C. 2009. 'Privatised Keynesianism: an unacknowleged policy regime.' The British Journal of Politics and International Relations 11 (3): 382-399. DOI: 10.1111/j.1467-856X.2009.00377.x.

Evans, J. 2019. 'Is for-profit investment in social housing a good or bad thing?' Financial Times 21/06/2019. Retrieved May 12, 2020, from https://www.ft.com/content/d667c6e4-605c11e9-9300-0becfc937c37.

Fields, D., S. Uffer 2016. 'The financialisation of rental housing: A comparative analysis of New York City and Berlin" Urban Studies 53 (7): 1486-1502. DOI: 0.1177/0042098014543704.

Fitzpatrick, S., H. Pawson, G. Bramley, J. Wood, B. Watts, M. Stephens, J. Blenkinsopp 2019. The homelessness monitor: England 2019. London: Crisis.

Gimat, M., B. Marot, B., M. Le Bon-Vuylsteke 2020. État des connaissances sur la vente de logements sociaux en Europe: Allemagne, France, Pays-Bas et Royaume-Uni. France: Institut CDC pour la recherche

Gurran, N., G. Bramley 2017. Urban planning and the housing market: international perspectives for policy and practice. Berlin: Springer.

Harloe, M. 2008. The people's home?: social rented housing in Europe and America. New Jersey: John Wiley \& Sons.

Haughton, G., P. Allmendinger 2016. 'Think tanks and the pressures for planning reform in England.' Environment and Planning C: Government and Policy 34 (8): 1676-1692. DOI: $10.1177 / 0263774 \times 16629677$.

Hulse, K., M. Reynolds, C. Martin 2019. 'The Everyman archetype: discursive reframing of private landlords in the financialization of rental housing.' Housing Studies (in press). First published online July 29, 2019. DOI: 10.1080/02673037.2019.1644297.

Jacobs, K., T. Manzi 2019. 'Conceptualising 'financialisation': governance, organisational behaviour and social interaction in UK housing.' International Journal of Housing Policy (in press). First published online January 23, 2019. DOI: 10.1080/19491247.2018.

JLL 2014. Brave New World: Examining the Case for Institutional Investment in Affordable Housing. London: Jones Lang LaSalle Research.

Legal \& General 2018. 'Legal \& General launches Affordable Housing arm.' Legal \& General 27/5/2018. Retrieved May 12, 2020, from https://www.legalandgeneralgroup.com/mediacentre/press-releases/legal-general-launches-affordable-housing-arm/.

McAllister, P. 2017. 'The calculative turn in land value capture: Lessons from the English Planning System.' Land Use Policy 63: 122-129. DOI: 10.1016/j.landusepol.2017.01.002. 
MHCLG 2019. 'Affordable Housing Supply: April 2018 to March 2019 England.' London: Ministry of Housing, Communities and Local Government.

Monoghan, A. 2018. Legal \& General aims to offer 3,000 affordable homes a year. The Guardian, 27/04/2018. Retrieved May 26, 2020, from https://www.theguardian.com/business/2018/apr/27/legal-general-affordable-homes

Murden, T. 2017. 'Blackrock injections $f 100 m$ into Wheatley' Daily Business 6/62017. Retrieved May 12,2020, from https://dailybusinessgroup.co.uk/2017/06/blackrock-injects-100m-intowheatley/.

National Housing Federation, 2017. 'Social housing spending at record low.' London: NHF.

Nethercote, M. 2019. 'Build-to-Rent and the financialization of rental housing: future research directions.' Housing Studies 35 (5): 839-874. DOI: 10.1080/02673037.2019.1636938.

Preece, J., P. Hickman, B. Pattison 2019. 'The affordability of "affordable" housing in England: conditionality and exclusion in a context of welfare reform.' Housing Studies (in press). First published online August 22, 2019 DOI: 10.1080/02673037.2019.165344.

Ronald, R., C. Lennartz, J. Kadi 2017. 'What ever happened to asset-based welfare? Shifting approaches to Housing Wealth and Welfare Security.' Policy \& Politics 45 (2): 173-193. DOI: 10.1332/030557316X14786045239560.

Ronald, R.. J. Kadi 2018. 'The revival of private landlords in Britain's post-homeownership society'. New Political Economy 23 (6): 786-803. DOI: 10.1080/13563467.2017.1401055.

Roper, N., T. Frain 2019. 'For-profit registered providers: what should their debt look like?' Social Housing 10/06/2019. Retrieved May 12, 2020 from, https://www.socialhousing.co.uk/comment/comment/for-profit-registered-providers-whatshould-their-debt-look-like-61829.

Savills, 2019. 'UK Residential, December 2019 - Private Money and Affordable Housing.' London: Savills.

Simpson, J. 2019. 'L\&G Affordable Homes Boss: 'We are not bidding up prices on affordable housing.' Inside Housing 24/10/2019. Retrieved May 12, 2020, from https://www.insidehousing.co.uk/news/news/lg-affordable-homes-boss-we-are-notbidding-up-prices-on-affordable-housing-63799.

Slater, T. 2016. 'Free market think tanks and the production of ignorance.' Pp. 370 in S. Springer, K. Birch, J. MacLeavy (eds.) Handbook of Neoliberalism. New York: Routledge.

Smith, S. J. 2015. 'Owner occupation: at home in a spatial, financial paradox.' International Journal of Housing Policy 15 (1): 61-83. DOI: 10.1080/14616718.2014.997432.

Smyth, S. 2019. 'Embedding financialization: a policy review of the English Affordable Homes Programme.' Housing Studies 34 (1): 142-161. DOI: 10.1080/02673037.2018.1442561.

Stephens, M. 2019. 'Land value capture through planning and taxation.' Pp. 11-18 in M. Stephens, J. Perry, P. Williams, G. Young (eds.) UK Housing Review 2019. Chartered Institute of Housing: Coventry.

Tang, C., M. Oxley, D. Mekic 2017. 'Meeting commercial and social goals: Institutional investment in the housing association sector.' Housing Studies 32 (4): 411-427. DOI: 10.1080/02673037.2016.1210098.

Tapp, R. 2019. 'Layers of finance: Historic tax credits and the fiscal geographies of urban redevelopment.' Geoforum 105: 13-22. DOI: 10.1016/j.geoforum.2019.06.016.

Van Gent, W., C. Hochstenbach 2020. 'The neo-liberal politics and socio-spatial implications of Dutch post-crisis social housing policies.' International Journal of Housing Policy 20 (1): 156-172. DOI: 10.1080/19491247.2019.1682234. 
Villegas, A. 2018. 'Blackrock ocntinues social housing drive.' Real Estate Capital News 1/8/2018. Retrieved May 12, 2020, from https://www.recapitalnews.com/blackrock-continues-socialhousing-drive/.

Wainwright, O. 2014. 'The truth about property developers: how they are exploiting planning authorities and ruining our cities.'The Guardian 17/09/2014. Retrieved May 12, 2020, from https://www.theguardian.com/cities/2014/sep/17/truth-property-developers-buildersexploit-planning-cities.

Wainwright, T., G. Manville 2017. 'Financialization and the third sector: Innovation in social housing bond markets.' Environment and Planning A 49 (4): 819-838. DOI: 10.1177/0308518X16684140.

Waldron, R. 2018. 'Capitalizing on the State: The political economy of Real Estate Investment Trusts and the 'Resolution'of the crisis.' Geoforum 90: 206-218. DOI: 10.1016/j.geoforum.2018.02.014.

Waldron, R. 2019. 'Financialization, urban governance and the planning system: Utilizing 'Financial Viability' as a policy narrative for the liberalization of Ireland's Post-Crash Planning System.' International Journal of Urban and Regional Research 43 (4): 685-704. DOI: 10.1111/14682427.12789.

Whitehead, C.M. 1993. 'Privatizing Housing: An Assessment of U.K. Experience.' Housing Policy Debate 4 (1): 101-139. DOI: 10.1080/10511482.1993.9521126.

Whitehead, C. M. 2007. 'Planning policies and affordable housing: England as a successful case study?' Housing Studies 22 (1), 25-44. DOI: 10.1080/02673030601024580.

Wijburg, G., M. B. Aalbers, S. Heeg 2018. 'The financialisation of rental housing 2.0: Releasing housing into the privatised mainstream of capital accumulation.' Antipode 50 (4): 1098-1119. DOI: 10.1111/anti.12382.

Wijburg, G. 2019. 'Reasserting state power by remaking markets? The introduction of real estate investment trusts in France and its implications for state-finance relations in the Greater Paris region.'Geoforum 100: 209-219. DOI: 10.1016/j.geoforum.2019.01.012.

Williams, A. 2018. 'Blackstone under fire over push into UK social housing.' The Financial Times 11/05/2018. Retrieved May 12, 2020, from https://www.ft.com/content/6a68b7c8-4ec911e8-9471-a083af05aea7.

Wilcox, S., J. Perry, M. Stephens, P. Williams 2017. UK Housing Review, 2017. Coventry: Chartered Institute for Housing.

Wilson, W., A. Bate 2015. Affordable Rents (England) (House of Commons Library Briefing Paper No. 05933). Retrieved from House of Commons Library website: https://commonslibrary.parliament.uk/research-briefings/sn05933/.

Wilson, R. 2019. 'Are HAs falling out with Section 106?' Social Housing 08/05/2019. Retrieved May 12, 2020, from https://www.socialhousing.co.uk/insight/insight/are-has-falling-out-with-section$106-61321$.

Wyatt, P. 2018. 'Can land value uplift deliver affordable housing? Experiences from England.' Journal of European Real Estate Research 11 (1): 87-101. DOI: 10.1108/JERER-02-2017-0009. 


\section{End notes}

\footnotetext{
i Total affordable housing is the sum of affordable rent, social rent, intermediate rent, London affordable rent, and affordable homeownership/shared ownership (MHCLG 2019).

ii In recent decades many UK housing associations have already become commercialised as mixed-income developments have been promoted to fund the lower-income housing schemes (Beswick and Penny 2018). However, now that for-profit vehicles can be established, the degree of commercialisation has taken another turn, as profits no longer have to be allocated for new housing production.

iii Historically, the total of partial grand funding and nil grant funding represented the total of s.106 contributions. However, partial grant funding used to be much more prevalent but recently the vast majority of s.106 funded units are nil grant (MHCLG 2019). For that reason, nil grant funding can be considered illustrative of how the qualitative nature of s.106 contributions has changed in recent years. However, we refer to Stephens' (2019) analysis for the importance of partial grants during the early 2000s.

iv FPRP's hiring of sales managers to promote shared ownership schemes among sitting tenants nevertheless exemplifies the importance of shared ownership as a business model. Shared ownership valuations are determined at $100 \%$ of the market value even if only a percentage (25-75\%) of the property is sold to the tenant. As such, a profitable margin emerges because affordable rents are determined at up to $80 \%$ of market value. Through shared ownership schemes, maintenance costs are also transferred to the (partial) homeowner, enabling a FPRP to cut expenses and to boost cash-on-cash returns.

$\checkmark$ Of course, some housing associations also need to reinvest in new housing projects and henceforth require a degree of profitability to stay operational. As a rule of thumb, however, 'for-profits' are expected to deliver higher investment returns.
} 